\title{
Stress Degradation Studies of Riociguat, Development of Validated Stability Indicating Method, Identification, Isolation and Characterization of Degradation Products by LC-HR-MS/MS and NMR Studies
}

\author{
Charu P Pandya, Sadhana J Rajput* \\ Department of Pharmaceutical Quality Assurance, Faculty of Pharmacy, The Maharaja Sayajirao University of Baroda, Center of \\ Relevance and Excellence in New Drug Delivery System, Government of India, Vadodara, Gujarat, INDIA.
}

\begin{abstract}
Aim: The present study reports the degradation behavior of new antihypertensive drug Riociguat under various stress conditions as per International Conference on Harmonization guidelines $\mathrm{ICH}, \mathrm{Q} 2(\mathrm{R} 1)$. Materials and Methods: Riociguat was subjected to stress degradation under hydrolytic (acidic, alkaline and neutral), oxidative, photolytic and thermal stress conditions to investigate the inherent stability. A rapid, accurate, precise and robust HPLC method was developed on Waters Symmetry $C_{18}$ Column $(150 \mathrm{~mm} X$ $4.6 \mathrm{~mm}, 5 \mu$ ) using isocratic elution of $10 \mathrm{~mm}$ ammonium acetate buffer $\mathrm{pH} 5.7$ and acetonitrile in the ratio of 70:30 with the flow rate at $1.0 \mathrm{~mL} / \mathrm{min}$. The detection was performed at $254 \mathrm{~nm}$. Results: The drug was found to be degraded in alkaline and oxidative condition whereas it was stable under acidic, neutral hydrolytic, thermal and photolytic conditions. Two degradation products (DP1, DP2) under alkaline condition and one under oxidative condition (DP3) were characterized by LC-HR-MS/MS with accurate mass measurements. Degradation products (DP1, DP2 and DP3) were isolated by preparative HPLC and were characterized by ${ }^{1} \mathrm{H}$ NMR, ${ }^{13} \mathrm{C}$ NMR, APT and IR Techniques. Conclusion: Using spectral data analysis, alkaline degradation product DP1 wascharacterized as 2-(1-(2-fluorobenzyl)-1 H-pyrazolo[3,4-b]pyridin-3-yl)-N5-methylpyrimidine-4, 5, 6-triamine and DP2 was characterized as 2-(1-(2-fluorobenzyl)-1H-pyrazolo[3,4-b]pyridin-3-yl)6-amino-7-methyl-7H-purin-8(9H)-one while oxidative degradation product DP3was characterized as methyl 2-(1-(2-fluorobenzyl)-1H-pyrazolo[3,4-b]pyridin-3-yl)-4,6diaminopyrimidin-5-ylmethylcarbamate- $\mathrm{N}$-oxide. The developed chromatographic method was validated in terms of specificity, linearity, accuracy, precision as per ICH guidelines. The robustness of the method was studied with 2 -level fractional factorial design $2^{\wedge 4-1}$.
\end{abstract}

Key words: Riociguat, Stress degradation, RP-HPLC, LC-HR-MS/MS, Preparative HPLC, NMR.

\section{INTRODUCTION}

Riociguat (RIO) (Figure 1a) is the first drug which belongs to the class of soluble guanylate cyclase stimulator. ${ }^{1,2}$ Nitric oxide when it binds to soluble guanylate cyclase, results in the synthesis of Cyclic Guanosine Monophosphate (cGMP) which regulates the mechanism of blood pressure. Pulmonary hypertension is characterized by impaired synthesis of nitric oxide and insufficient stimulation of nitric-oxide-s guanylate cyclase- guanosine monophosphate (cGMP) pathway. RIO has dual mode of action. ${ }^{3}$ It stimulates sGC to nitric oxide and stabilizes NO-sGC binding thereby it causes relaxes of vascular smooth muscle. It has antiproliferative and antifibrinolytic effects. RIO
Submission Date: 05-04-2019; Revision Date: 12-06-2019; Accepted Date: 10-09-2019

DOI: 10.5530/ijper.53.4s.159 Correspondence:

Prof. Sadhana J Rajput, Department of Pharmaceutical Quality Assurance, Faculty of Pharmacy, The

Maharaja Sayajirao University of Baroda, Center of Relevance and Excellence in New Drug Delivery System, Government of India,

Vadodara-390002, Gujarat, INDIA.

Phone: +919662060501 E-mail: sjrajput@rediffmail. com

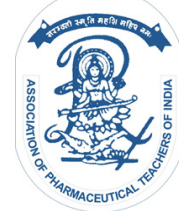

www.ijper.org 
is the first drug used in two forms of hypertension chronic thromboembolic pulmonary hypertension and pulmonary arterial hypertension. ${ }^{4}$ RIO was approved by USFDA in 2013. It is available as Adempas ${ }^{\circledR}$ by Bayer Healthcare pharmaceuticals. ${ }^{5}$ The dose of RIO is starting from $0.5 \mathrm{mg}$ thrice daily. ${ }^{6} \mathrm{RIO}$ is white, crystalline, nonhygroscopic powder with a molecular weight of $423 \mathrm{~g} /$ mole and a molecular formula of $\mathrm{C}_{20} \mathrm{H}_{19} \mathrm{FN}_{8} \mathrm{O}_{2}$ RIO is insoluble in water, slightly soluble in acetone, methanol, freely soluble in dimethylsulphoxide and dimethylformamide.

There are few literatures available for riociguat. Literature has been reported on method development of riociguatin API by UV-visible spectroscopy. ${ }^{7}$ There is a literature on method development of riociguatin dosage form by HPLC ${ }^{8}$ and LC-MS. ${ }^{9}$ Literature has been reported for development of riociguat and metabolite in LC-MS/MS and LC-Q-TOF-MS/MS. ${ }^{10,11}$

Stress testing is an important part of drug development process. Guidelines by International Conference on Harmonization ICH Q3A(R2) and Q3B(R2) ${ }^{12,13}$ emphasizes that stress studies should be performed on drug to establish its inherent stability characteristics leading to identification of degradation products.Structural elucidation of unknown degradation products is also required to determine whether degradation products have toxicity. Comprehensive details on degradation behaviour of drugs help in maintaining its quality and pharmaceutical safety.

Robustness testing was performed to obtain information about critical parameters affecting the responses (retention time, peak area, tailing factor, theoretical plates). AQbD plays an important role in developing a robust method as an early risk assessment and helps to identify the critical analytical parameters and to focus on the method development. ${ }^{14,15}$ Experimental design is a good alternative approach than traditional approach (OVAT) for proper planning and conduct of study. ${ }^{16}$ To study the simultaneous variations of the factors on the considered responses, a multivariate approach DoE with fractional factorial design was applied. In the present work, DoE has been employed to check the robustness of the method.

To the best of our knowledge there are no reports on development of stability indicating method and force degradation studies of RIO by mass spectrometry for identification of degradation products. Aim of the present work is (i) to investigate the degradation behavior of RIO under different stress conditions (hydrolytic, oxidative, photolytic and thermal) and to develop SIAM for separation of RIO from its degradation products (ii) to isolate the major degradation
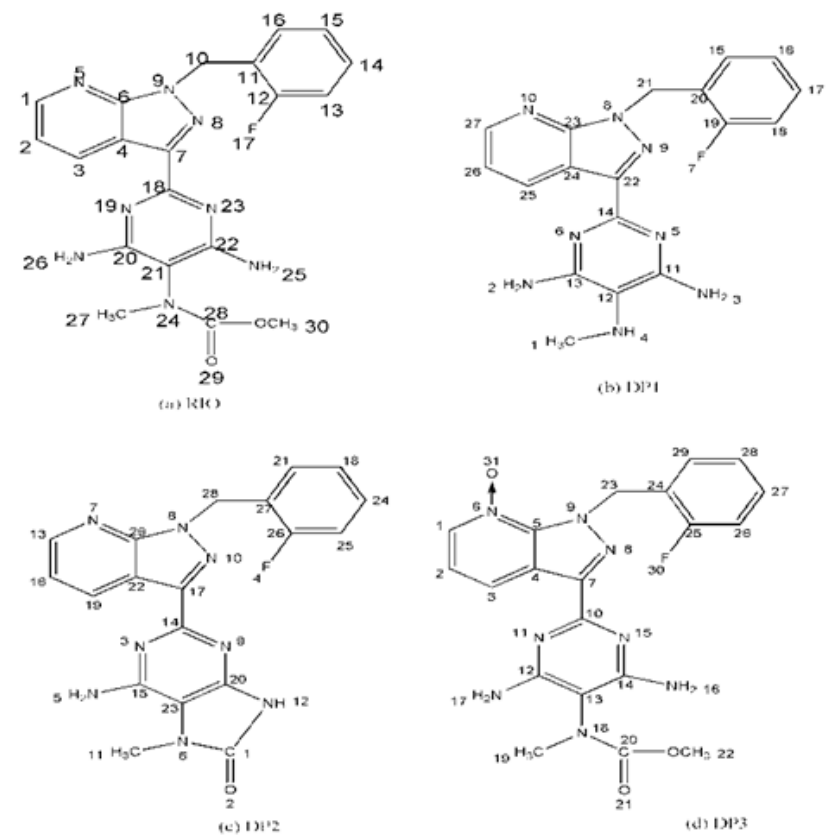

Figure 1: Structures of RIO, DP1, DP2 and DP3.

products by preparative HPLC and their characterization by LC-HR-MS/MS, NMR and IR techniques (iii) to predict degradation pathway of RIO(iv) validation of the developed method as per the guidelines by ICH (v) quality by design approach to check the robustness of the developed method using fractional factorial $2^{\wedge 4-1}$ design.

\section{MATERIALS AND METHODS}

RIO standard drug was procured from Angene Chemical Ltd, China. HPLC grade acetonitrile and acetic acid were purchased from Rankem Pvt. Ltd, India. Ammonium acetate of HPLC grade was procured from LobaCheme Pvt. Ltd, Mumbai, India. Hydrochloric acid, sodium hydroxide and hydrogen peroxide were procured from SD Chemical Pvt. Ltd. Mumbai, India.

\section{Equipments and Chromatographic conditions}

Degradation study was performed with precision water baths (Thermal Lining Services, Vadodara, India) with a temperature controller. Degradation under photolytic condition was carried in photolytic chamber (Thermolab Scientific Equipments Pvt. Ltd., Vadodara, India) comprising of light bank having four UV (Osram L73) and fluorescent (L20) lamps. Design Expert $^{\mathbb{B}} 7.0 .0$ software $\left(\mathrm{DX}^{\circledR}\right.$ 7.0.0) was to obtain DoE design matrix for robustness study.

For HPLC, method development was performed on (Shimadzu Corporation, Kyoto, Japan) chromatographic system equipped with Shimadzu LC-20AD pump 
(binary) and Shimadzu PDA M20A Diode Array detector with LC solution software), $\mathrm{C}_{18}$ Column (Waters Symmetry, 150X $4.6 \mathrm{~mm}, 5 \mu)$. The detection was done at $254 \mathrm{~nm}$ with flow rate of $1 \mathrm{~mL} / \mathrm{min}$. Samples were injected through Rheodyne 7725 injector valve with a fixed loop at $20 \mu \mathrm{L}$. For HPLC (Preparative), chromatographic separation was performed on Shimadzu (Shimadzu Corporation, Kyoto, Japan) chromatographic system equipped with Shimadzu LC-20AP pump (binary) and Shimadzu SPD-20A UV-visible detector. Samples were injected through Rheodyne 7725 injector valve. Data acquisition and integration was performed using Class VP software. Promosilcolumn (250X $50 \mathrm{~mm}, 10 \mu$ ) wasused for isolation of degradation. The flow rate was kept at $55 \mathrm{~mL} / \mathrm{min}$. Detection was performed at $254 \mathrm{~nm}$. The gradient programme was (time/\% Acetonitrile): 0/30, 45/35, 46/100, 50/100, 55/30, 60/30.

${ }^{1} \mathrm{H}$ and ${ }^{13} \mathrm{C}$ NMR spectra were recorded on Bruker Avance II 400 NMR spectrometer using solvent DMSO d- ${ }_{6}$ as solvent and Tetramethylsilane as internal standard. IR spectra were recorded on Shimadzu $8400 \mathrm{~s}$ spectrophotometer. For LC-HRMS/MS analysis, system was Q-Extractive plus Biopharma High Resolution Orbitrap Liquid Chromatograph Mass Spectrophotometer (Thermo Fischer Scientific Pvt. Ltd.) equipped with electro spray ionization source in a positive mode. Xcalibur software was used for mass spectroscopic studies.

\section{Preparation of stock and buffer solutions}

Stock solution of RIO $(1 \mathrm{mg} / \mathrm{mL})$ was prepared by weighing accurately $25 \mathrm{mg}$ of RIO in $25 \mathrm{~mL}$ of volumetric flask and dissolved in acetonitrile and making up the volume with acetonitrile. From this solution, solutions were prepared in the concentration ranging from 5 to $160 \mu \mathrm{g} / \mathrm{mL}$.

Buffer used in the mobile phase was acetate buffer $(10 \mathrm{~mm})$ which was prepared by dissolving $77 \mathrm{mg}$ of ammonium acetate in $100 \mathrm{~mL}$ of double distilled water and adjusted to $\mathrm{pH} 5.7$ with acetic acid. Mobile phase composed of acetate buffer and acetonitrile in the ratio of $70: 30$.

\section{Validation of developed HPLC method ${ }^{17,18}$}

The developed HPLC method was validated in terms of linearity, sensitivity, precision, robustness in accordance with ICH Q2(R1) guideline and system suitability test.

Robustness: Robustness was evaluated by QbD approach.Four Factor Factorial Designs (FFD) was employed $\left(2^{\wedge 4-1}\right)$. Factors were varied over at two levels +1 and -1 denoting the maximum level and minimum level of particular factor respectively. The factors considered for development of design were $\mathrm{pH}$ of buffer, $\%$ organic, flow rate and wavelength. Design expert software was used to predict the percentage contribution of each factor followed by ANOVA statistical analysis, along graphical representation of Pareto charts, perturbation plots, 3Dresponse surface plots and contour plots.

Specificity: Specificity of the method was performed to ensure that there was no on interference from the degradation products, excipients and other impurities. Specificity of the method was done by performing forced degradation study. RIO was subjected to hydrolytic, oxidative, thermal and photolytic conditions as per conditions prescribed by ICH guidelines. For forced degradation study, stock solution of RIO $1 \mathrm{mg} / \mathrm{mL}$ was prepared in water: acetonitrile (50:50). Stock solutions of RIO were diluted with $1 \mathrm{M} \mathrm{HCl}$, water, $0.5 \mathrm{M} \mathrm{NaOH}$, $10 \%$ hydrogen peroxide in 1:1 ratio and were kept at $80^{\circ} \mathrm{C}$ for $12 \mathrm{hr}(1 \mathrm{M} \mathrm{HCl}$, water $), 60^{\circ} \mathrm{C}$ for $4 \mathrm{hr}(0.5 \mathrm{M}$ $\mathrm{NaOH})$ and at room temperature for $2 \mathrm{hr}(10 \%$ hydrogen peroxide) respectively. Effect of dry heat (thermal degradation) was performed on solid state. RIO was spread in a petridish and kept in an oven at $80^{\circ} \mathrm{C}$ for 11 days under dry heat conditions. During photodegradation, solid drug powder and solution form was exposed to florescent light (1.25 million lux hours) and UV light $\left(200 \mathrm{Whm}^{-2}\right)$ in a photostability chamber. All degradation samples (acid, base were neutralized with $1 \mathrm{M} \mathrm{NaOH}$ and $0.5 \mathrm{M} \mathrm{HCl}$ ) were diluted to concentration of $100 \mu \mathrm{g} / \mathrm{mL}$ with mobile phase.

\section{Isolation of major degradation products}

Three major degradation products DP1, DP2 under alkaline condition and DP3 under oxidative condition were isolated and purified by preparative HPLC. The degradation products were characterized by LC-HRMS/MS, NMR and IR techniques.

\section{RESULTS AND DISCUSSION}

\section{Method development and optimisation}

An attempt has been made to develop stability indicating RP-HPLC method for determination of RIO in presence of its degradation products. From the literature (Table 1), it is evident that reported methods are based on determination of RIO by spectrophotometric, HPLC, LC-MS methods which were summarized in the comparative study given in Table 1 and compared with the present method. Compared to the reported methods in the literature, detection wavelength of $254 \mathrm{~nm}$ was selected due to its sensitivity for all degradation products. For separation of degradation 


\begin{tabular}{|c|c|c|c|}
\hline \multicolumn{2}{|c|}{ Table 1: Comparison of previously reported methods for RIO with present method. } \\
\hline Mobile Phase /Reagent & Wavelength & Method & UV \\
\hline Methanol & 323 & HPLC & 7 \\
\hline $0.2 \%$ TFA and acetonitrile (60:40) & $254 \mathrm{~nm}$ & LC-MS/MS & 9 \\
\hline $0.1 \%$ formic acid and acetonitrile (15:85) & -- & LC-MS/MS & 10 \\
\hline Ammonium formate $(\mathrm{pH} 6.8)$ and acetonitrile in gradient elution & -- & LC-Q-TOF-MS/MS & 11 \\
\hline $0.1 \%$ formic acid and acetonitrile in gradient elution & -- & HPLC & Present method \\
\hline Ammonium acetate buffer $\mathrm{pH}(5.7)$ and acetonitrile $(70: 30)$ & $254 \mathrm{~nm}$ & & \\
\hline
\end{tabular}

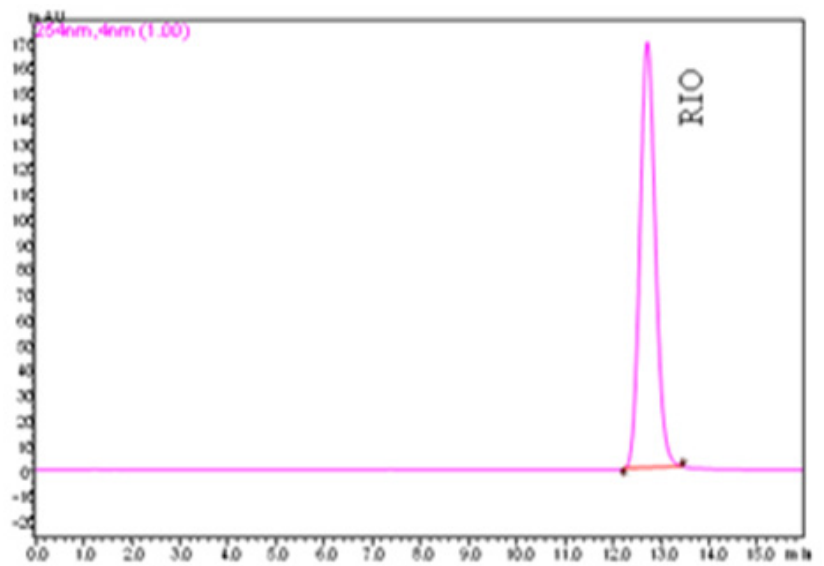

Figure 2: Chromatogram of RIO $100 \mu \mathrm{g} / \mathrm{mL}$.

products from $\mathrm{RIO}$, mobile phase with $0.1 \%$ formic acid and ammonium formate buffer in $\mathrm{pH} 3,4$ were tried but degradation products were co-eluting with RIO and were eluting fast.Ammonium acetate buffer in the $\mathrm{pH}$ range 4-6 was tried, $10 \mathrm{~mm}$ ammoniumacetate $\mathrm{pH} 5.7$ was found to be suitable for resolution of degradation products and retention time of RIO. Acetonitrile was found to be better in terms or resolution and peak shape if RIO. Method was developed with mobile phase containing $10 \mathrm{~mm}$ ammonium acetate and acetonitrile in the ratio of 70:30 on Waters Symmetry $\mathrm{C}_{18}$ column with flow rate of $1.0 \mathrm{~mL} / \mathrm{min}$. RIO eluted at $12.44 \pm 0.049 \mathrm{~min}$ with run time of 20 min. (Figure 2).

\section{Method Validation}

For system suitability parameters, solution of RIO was injected six times into the HPLC system. RIO eluted at $12.44 \pm 0.049 \mathrm{~min}$. Tailing factor was less than 2 and theoretical plates were greater than 2000. The results of system suitability parameters of RIO are shown in Table 2.

The developed method was validated for various parameters as per ICH guidelines. For linearity, good correlation was observed between peak area and concentrationwith regression coefficient $r^{2} 0.9997$ in

\begin{tabular}{|c|c|}
$\begin{array}{c}\text { Table 2: System suitability and validation parameters } \\
\text { of RIO. }\end{array}$ \\
\hline System suitability parameters & Values \\
\hline Retention Time $(m i n \pm S D)$ & $12.44 \pm 0.049$ \\
\hline Tailing Factor \pm SD & $1.124 \pm 0.003$ \\
\hline Theoretical Plates \pm SD & $7866.378 \pm 372.177$ \\
\hline Validation Parameters & Values \\
\hline Linearity range $(\mu g / m L)$ & $5-160$ \\
\hline Regression Equation & $y=49420 x-35097$ \\
\hline Correlation coefficient & 0.9997 \\
\hline LOD $(\mu g / m L)$ & 0.046 \\
\hline LOQ $(\mu g / m L)$ & 0.139 \\
\hline Intra-day precision $(\% R S D)$ & 1.229 \\
\hline Inter-day precision $(\% R S D)$ & 1.418 \\
\hline$\% R e c o v e r y \pm S D$ & $99.11 \% \pm 0.80-$ \\
& $100.05 \% \pm 0.36$ \\
\hline
\end{tabular}

the concentration ranging from $5-160 \mu \mathrm{g} / \mathrm{mL}$. Limit of detection was found to be $0.046 \mu \mathrm{g} / \mathrm{mL}$ and Limit of quantification was found to be $0.139 \mu \mathrm{g} / \mathrm{mL}$. Precision of the method was performed by repeatability and interday precision in the concentration from $5-160 \mu \mathrm{g} / \mathrm{mL}$. $\%$ RSD value was found to be less than $2 \%$. The developed method was precise. Accuracy of the method was performed by standard addition method. Standard solution of RIO was added at three concentration levels (50, 100 and $150 \%$ ) were added to the sample solutions and analysis were done in triplicate $(n=3) . \%$ Recovery were found to be in the range of $99.11-100.05 \%$ and $\%$ RSD was found to be less than 2 . The developed method was found to be accurate. The results of validation parameters are summarized in Table 3.

Robustness -QbD- a fractional factorial method DoE strategy was used to carry out robustness study as summarized in Table 3. The robustness was adjudged by employing Res III FFD. The design matrix used consisted of $2^{\wedge} 4-1$ with factors being varied over two levels viz. minimum and maximum. Total of four Critical Method Parameters (CMPs) were selected viz., $\mathrm{pH}$, $\%$ organic, flow rate, wavelength each varied at two lev- 
Table 3: Fractional factorial design for robustness testing using factors and obtained responses.

\begin{tabular}{|c|c|c|c|c|c|c|c|}
\hline \multicolumn{3}{|c|}{ Factors } & \multicolumn{5}{c|}{ Responses } \\
\hline A: $\mathrm{pH}$ & B: \% Organic & C: Flow rate & D: wavelength & Retention Time & Area & Tailing Factor & Theoretical Plates \\
\hline 5.9 & 32 & 0.9 & 252 & 12.95 & 1682854 & 1.123 & 7863 \\
\hline 5.5 & 32 & 1.1 & 252 & 12.54 & 1685283 & 1.118 & 7864 \\
\hline 5.5 & 28 & 0.9 & 252 & 12.94 & 1683827 & 1.093 & 7864 \\
\hline 5.5 & 28 & 1.1 & 256 & 12.52 & 1682742 & 1.122 & 7863 \\
\hline 5.5 & 32 & 0.9 & 256 & 12.94 & 1683823 & 1.117 & 7863 \\
\hline 5.9 & 28 & 1.1 & 252 & 12.62 & 1683826 & 1.116 & 7864 \\
\hline 5.9 & 32 & 1.1 & 256 & 12.48 & 1682384 & 1.122 & 7864 \\
\hline 5.9 & 28 & 0.9 & 256 & 12.98 & 1684721 & 1.113 & 7864 \\
\hline
\end{tabular}

els. Four Critical Quality Attributes (CQAs) taken were retention time, area, tailing factor and number of theoretical plates.

Among the various models, polynomial model was suggested by the design with the highest least square regression value for all responses as compared to other models. The model was examined using lack of fit test, which indicted insignificant lack of fit value corresponding with higher $p$-value as compared to the model F-value. Graphical interpretation in the form of Pareto charts, perturbation plots, 3-D response surface plots and contour plotsshowed the correlation of effect of factors on the responsesretention time, area, tailing factor and theoretical plates of RIO.

Pareto charts and perturbation plots indicated (Figure 3a-d and 3e-h) that none of the factors had significant effect on responses. The model was evaluated for the effect of individual factors on the responses in the form of 3-D response surface plots and contour plots. The 3-D response surface plots showed that when flow rate and wavelength were kept constant at $1.0 \mathrm{ml} / \mathrm{min}$ and $254 \mathrm{~nm}$ respectively, there was no considerable variation in responses (retention time, area, tailing factor and theoretical plates). 3-D response surface plots and contour plots indicated that the effect of all the responses are independent of the factors $\mathrm{pH}$, $\%$ Organic, flow rate and theoretical plates (Figure 4a-d and Figure 4e-h).

Further model was validated by the application of Analysis of Variance (ANOVA) to all response variables to examine the significance of the model, which showed that all the responses achieved are insignificant differences in their values (Table 4).

Equations obtained from the model were as:

Retention Time $\mathrm{Y} 1=+12.65+0.012 * \mathrm{~A}-0.11 * \mathrm{C}$ $-0.068 * \mathrm{D}-0.047 * \mathrm{~A} * \mathrm{C}$

Area $\mathrm{Y} 2=+1.683 \mathrm{E}+006-111.00 * \mathrm{~A}-249.00 * \mathrm{C}-139.75^{*}$ $\mathrm{D}+408.00 * \mathrm{~A} * \mathrm{C}-254.25 * \mathrm{~A} * \mathrm{D}$

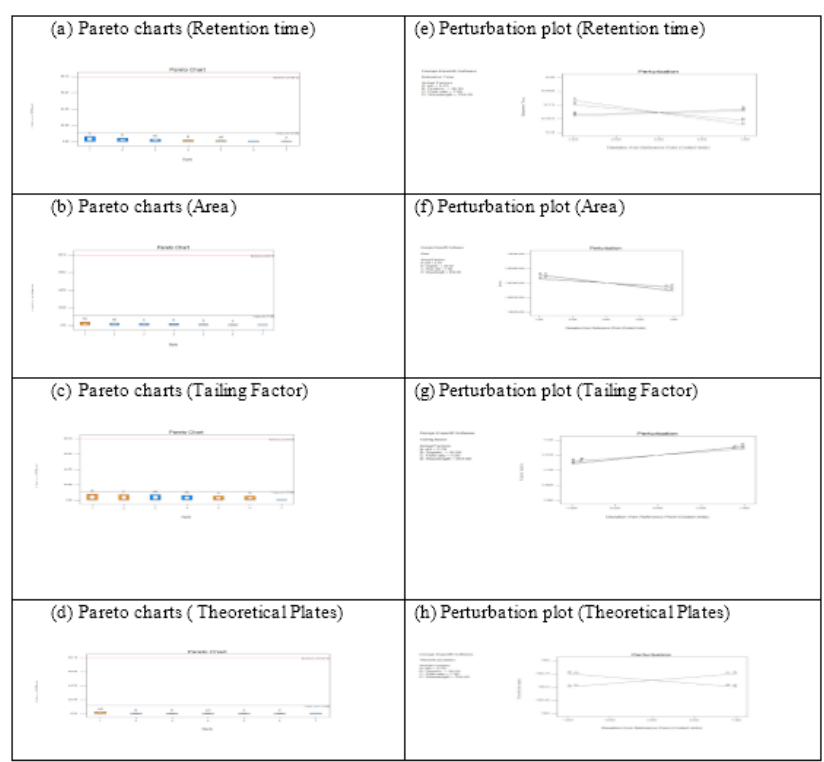

Figure 3: Pareto charts (a-d) and perturbation plots (e-h) showing effect of factorson responses.

Tailing factor $\mathrm{Y} 3=+1.12+4.500 \mathrm{E}-003 * \mathrm{~B}+4.000 \mathrm{E}-003 *$ C

Theoritical plates $\mathrm{Y} 4=+7863.63+0.12 * \mathrm{~A}-0.13$ $* \mathrm{~B}-0.13 * \mathrm{D}+0.38 * \mathrm{~A} * \mathrm{D}$

From the equations, positive sign indicates synergistic effect, negative sign indicates antagonistic effect in the polynomial equation. From the table of ANOVA, responses $\mathrm{Y} 1, \mathrm{Y} 2, \mathrm{Y} 3$ and $\mathrm{Y} 4$ indicated that predicted values for all the factors are under satisfactory value. Model $p$ value $>0.05$ indicatesthat factors had nonsignificant on the responses resulting in a robust method.

Selectivity: Selectivity of the developed method was determined by peak purity analysis of all chromatographic peaks by using PDA detector. All peaks were well separated from each other with optimum resolution and peak puritywas found to be greater than 


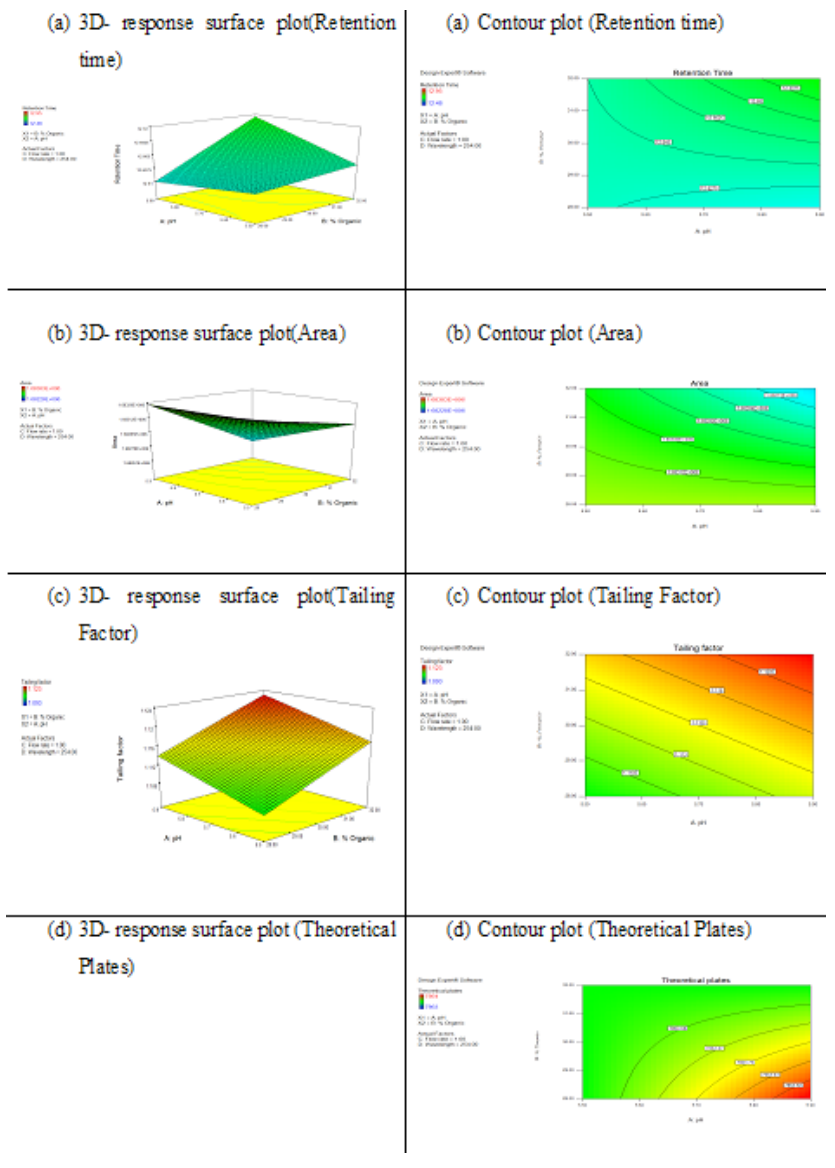

Figure 4.3: D response surface plots (a-d) and contour plots $(e-h)$ showing effect of factors on responses. purity threshold. Hence the developed method was selectively stability indicating.

\section{Forced degradation study}

Hydrolytic degradation: No degradation was observed when RIO was subjected to acidic hydrolysis $1 \mathrm{M} \mathrm{HCl}$ at $80^{\circ} \mathrm{C}$ for $12 \mathrm{~h}$ and neutral hydrolysis at $80^{\circ} \mathrm{C}$ for $12 \mathrm{hr}$. RIO showed $12.8 \%$ degradation in $0.1 \mathrm{M} \mathrm{NaOH}$ at $60^{\circ} \mathrm{C}$ for $4 \mathrm{~h}$. In alkaline degradation two degradation products were formed DP1 (10.6\%) and DP2 (2.2\%) at retention time of $11.4 \mathrm{~min}$ and $9.4 \mathrm{~min}$ (Figure $5 \mathrm{a}$ ).

Oxidative condition: RIO showed $9.8 \%$ degradation in $10 \%$ hydrogen peroxide at room temperature for $2 \mathrm{hr}$. One degradation product DP3 was formed at retention time of $4.1 \mathrm{~min}$ (Figure $5 \mathrm{~b}$ ).

Thermal degradation: RIO was stable to dry heat at $80^{\circ} \mathrm{C}$ for a period of 11 days.

Photolytic degradation: No degradation was observed when RIO in solid state and solution form was exposed to exposed to fluorescent light (1.25 million lux $\mathrm{h}$ ) and UV light $\left(200 \mathrm{Wh} / \mathrm{m}^{2}\right)$.

Forced degradation study is summarized in Table 5.

Isolation of degradation samples in alkaline and oxidative conditions

Alkaline degradation: For isolation of DP1 and DP2 in alkaline condition, DPs were enriched by preparing a solution of $1 \mathrm{~g}$ of RIO in $80 \mathrm{ml}$ of acetonitrile: water

\begin{tabular}{|c|c|c|c|c|c|c|c|c|}
\hline Parameters & ss & df & MS & F-value & p-value & $\begin{array}{c}\text { Model } \\
\text { F-value }\end{array}$ & $\begin{array}{c}\text { Model } \\
\text { p-value }\end{array}$ & Prob $>$ F \\
\hline \multicolumn{9}{|c|}{ Response Y1 (Retention Time) } \\
\hline $\mathrm{pH}$ & 0.0012 & 1 & 0.0012 & 0.6944 & 0.557 & 14.37 & 0.1992 & not significant \\
\hline$\%$ Organic & 0.0072 & 1 & 0.0072 & 4 & 0.295 & & & \\
\hline Flow rate & 0.0882 & 1 & 0.0882 & 49 & 0.090 & & & \\
\hline Wavelength & 0.0364 & 1 & 0.0364 & 20.25 & 0.139 & & & \\
\hline \multicolumn{9}{|c|}{ Response Y2 (Area) } \\
\hline $\mathrm{pH}$ & 98568 & 1 & 98568 & 0.1906 & 0.737 & 0.83 & 0.6856 & not significant \\
\hline$\%$ Organic & 393384.5 & 1 & 393384.5 & 0.7606 & 0.543 & & & \\
\hline Flow rate & 496008 & 1 & 496008 & 0.9591 & 0.506 & & & \\
\hline Wavelength & 156240.5 & 1 & 156240.5 & 0.3021 & 0.680 & & & \\
\hline \multicolumn{9}{|c|}{ Response Y3 (Tailing Factor) } \\
\hline $\mathrm{pH}$ & $7.2 \mathrm{E}-05$ & 1 & $7.2 \mathrm{E}-05$ & 36 & 0.105 & 55 & 0.1029 & not significant \\
\hline$\%$ Organic & 0.00016 & 1 & 0.0001 & 81 & 0.070 & & & \\
\hline Flow rate & 0.00012 & 1 & 0.0001 & 64 & 0.079 & & & \\
\hline Wavelength & $7.2 \mathrm{E}-05$ & 1 & $7.2 \mathrm{E}-05$ & 36 & 0.105 & & & \\
\hline \multicolumn{9}{|c|}{ Response Y 4 (Theoretical Plates) } \\
\hline $\mathrm{pH}$ & 0.125 & 1 & 0.125 & 1 & 0.500 & 2.33 & 0.463 & not significant \\
\hline$\%$ Organic & 0.125 & 1 & 0.125 & 1 & 0.500 & & & \\
\hline Flow rate & 0.125 & 1 & 0.125 & 1 & 0.500 & & & \\
\hline Wavelength & 0.125 & 1 & 0.125 & 1 & 0.500 & & & \\
\hline
\end{tabular}

SS- sum of squares, df - degrees of freedom, MS- Mean square. 

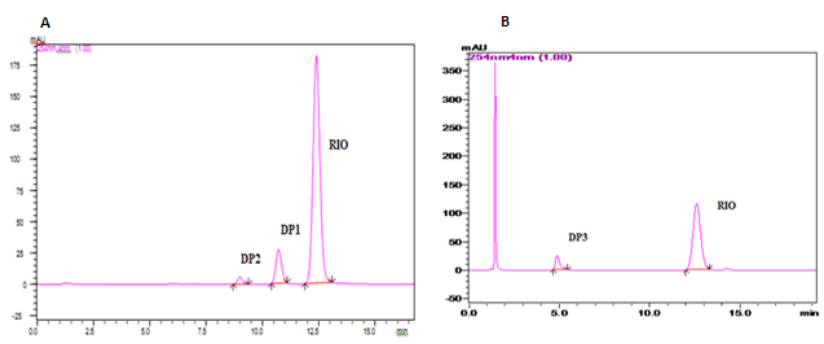

Figure 5: Chromatogram of (a) $0.1 \mathrm{M} \mathrm{NaOH}$ at $60^{\circ} \mathrm{C}$ for $4 \mathrm{~h}$ (b) $10 \%$ hydrogen peroxide at RT for $2 \mathrm{~h}$.
(2:1) and $20 \mathrm{~mL}$ of $1 \mathrm{M}$ sodium hydroxide. The solution was heated at $60^{\circ} \mathrm{C}$ for $24 \mathrm{hr}$. The solution was neutralized. \% degradation was checked by HPLC and was found to contain $50 \%$ of DP1 and $15 \%$ and DP2.

Oxidative degradation: For isolation of DP3 in oxidative condition, DP3 was enriched bypreparing a solution of $1 \mathrm{~g}$ of RIO in $80 \mathrm{ml}$ of acetonitrile: water (2:1) and $20 \mathrm{~mL}$ of $30 \%$ hydrogen peroxide. The solution was kept at room temperature for 24 h. \% deg-

\begin{tabular}{|c|c|c|c|c|}
\hline Stress Condition & Temperature $\left({ }^{\circ} \mathrm{C}\right)$ & Time (Hrs) & $\begin{array}{c}\text { RT of Degradation } \\
\text { Products }\end{array}$ & $\begin{array}{c}\% \text { of Degradation } \\
\text { Products in API }\end{array}$ \\
\hline Acid $(1 \mathrm{M} \mathrm{HCl})$ & $80^{\circ} \mathrm{C}$ & $12 \mathrm{hrs}$ & -- & --- \\
\hline Alkaline(0.1 M NaOH) & $60^{\circ} \mathrm{C}$ & $4 \mathrm{hrs}$ & $\begin{array}{c}9.4 \min (\mathrm{DP} 2) \\
11.4 \min (\mathrm{DP} 1)\end{array}$ & $12.8 \%$ \\
\hline Neutral & $80^{\circ} \mathrm{C}$ & $12 \mathrm{hrs}$ & -- & -- \\
\hline Oxidative $\left(10 \% \mathrm{H}_{2} \mathrm{O}_{2}\right)$ & RT & $2 \mathrm{hr}$ & $4.0 \mathrm{~min}(\mathrm{DP} 3)$ & $9.8 \%$ \\
\hline Thermal & $80^{\circ} \mathrm{C}$ & 11 days & -- & -- \\
\hline Photolytic Dry & \multirow{2}{*}{$\begin{array}{l}1.25 \text { million lux } h \\
\text { and } 200 W h / m^{2}\end{array}$} & 11 days & -- & -- \\
\hline Photolytic Solution & & 11 days & -- & -- \\
\hline
\end{tabular}

radation was checked by HPLC and was found to contain 10\% DP3.

Degradation products were isolated and purified by preparative HPLC. Fractions of greater than $95 \%$ were pooled together for DP1, DP2 and DP3 separately. Fractions were concentrated on rotary vapor to distill off acetonitrile. The solution so obtained was lyophilized. DP1 was obtained as yellow colored solid while DP2 and DP3 were obtained as white solids.

\section{Structural elucidation of RIO and degradation products}

\section{Structural elucidation of RIO}

MS/MS spectra: RIO was eluted at retention time of $12.44 \mathrm{~min}$. The ESIMS/MS spectrum of RIO shows protonated molecular ion peak $[\mathrm{M}+\mathrm{H}]^{+}$at $m / z$ of 423.1659 (Table 6) and product ions of $\mathrm{m} / \mathrm{z} 391$ (loss of methoxy group from $m / z 423$ ), $m / z 109$ (loss of $\mathrm{C}_{13} \mathrm{H}_{12} \mathrm{~N}_{8} \mathrm{O}_{2}$ from $m / z$ 423) (Figure 6a and 7).

NMR spectra: ${ }^{1} \mathrm{H}$ spectra of RIO shows the presence of methyl group and methoxy groups at 3.03 and 3.39 $\mathrm{ppm}$. Presence of methylene group is indicated by peak at $5.81 \mathrm{ppm}$. Methyl and methoxy groups are further confirmed in ${ }^{13} \mathrm{C}$ NMR spectra 34.72 and $52.51 \mathrm{ppm}$ and methylene group at $43.87 \mathrm{ppm}$. Two amino groups are pyrimidine ring are indicated in ${ }^{1} \mathrm{H}$ NMR spectra at 6.39 and $6.41 \mathrm{ppm}$ which are absent in $\mathrm{D}_{2} \mathrm{O}$ exchange.
Protons of pyridine ring are indicated at 9.06, 8.60 and $7.24 \mathrm{ppm}$. Protons of flurobenzene ring are indicated at 7.12, 7.19 and $7.32 \mathrm{ppm}$. Presence of carbamate group is indicated in ${ }^{13} \mathrm{C}$ NMR spectra at $155.52 \mathrm{ppm}$ (Table S1).

IR spectra: IR spectra of RIO indicates presence of two primary amino groups at 3508 and $3457 \mathrm{~cm}^{-1}$. Aromatic and methyl groups are merged in the region covering 3099, 3065 and $3035 \mathrm{~cm}^{-1}$. Presence of carbamate is indicated at $1688 \mathrm{~cm}^{-1}$ (Table 7).

\section{Structural elucidation of DP1}

MS/MS spectra: DP1 eluted at retention time of 11.4 min. ESI/MS/MS spectrum of DP1 shows protonated molecular ion peak at $\mathrm{m} / \mathrm{z}$ of 365.161 corresponding with elemental composition $\mathrm{C}_{18} \mathrm{H}_{17} \mathrm{FN}_{8}^{+}$(Table 6). It showsfragment ions of $\mathrm{m} / \mathrm{z} 256$ (loss of $\mathrm{C}_{7} \mathrm{H}_{5} \mathrm{~F}$ group from $m / z 365$ ), $m / z 241$ (loss of $\mathrm{NH}$ from $m / z 256$ ), $m / z 214$ (loss of $\mathrm{C}_{2} \mathrm{H}_{4} \mathrm{~N}$ from $\mathrm{m} / \mathrm{z}$ 256), $\mathrm{m} / \mathrm{z} 109$ (loss of $\mathrm{C}_{11} \mathrm{H}_{10} \mathrm{~N}_{8}$ from $\left.m / z 365\right), \mathrm{m} / \mathrm{z} 83$ ( loss of $\mathrm{C}_{2} \mathrm{H}_{2}$ from $m / z 109$ ) (Figure 6b and 7).

NMR spectra: In DP1, there is absence of methyl group and carbamate group. In ${ }^{1} \mathrm{H}$ NMR spectra there are absence of 3 protons which indicates loss of methyl group and other methyl group is shifted towards upfield at $2.51 \mathrm{ppm}$. There is formation of $-\mathrm{NH}$ at $4.00 \mathrm{ppm}$ which is absent in $\mathrm{D}_{2} \mathrm{O}$ exchange. ${ }^{13} \mathrm{C}$ NMR spectra of DP1 indicates absent of carbamate group at $155 \mathrm{ppm}$, 


\begin{tabular}{|c|c|c|c|c|c|}
\hline \multicolumn{2}{|c|}{ Table 6 : Elemental Composition of RIO and its degradation products. } \\
\hline RIO and its DPs & $\begin{array}{c}\text { Molecular Formula } \\
{\left[\mathbf{M}+\mathrm{H}^{+}\right.}\end{array}$ & Calculated $\mathbf{m} / \mathbf{z}$ & Observed $\mathbf{m} / \mathbf{z}$ & Error (ppm) & MS/MS fragment ions \\
\hline RIO & $\mathrm{C}_{20} \mathrm{H}_{19} \mathrm{FN}_{8} \mathrm{O}_{2}^{+}$ & 423.1649 & 423.1657 & -0.08 & 391,109 \\
\hline DP1 & $\mathrm{C}_{19} \mathrm{H}_{17} \mathrm{FN}_{8}{ }^{+}$ & 365.1561 & 365.1607 & -0.46 & $256,241,214,109,83$ \\
\hline DP2 & $\mathrm{C}_{19} \mathrm{H}_{15} \mathrm{FN}_{8} \mathrm{O}^{+}$ & 391.1323 & 391.1398 & -0.75 & 149,109 \\
\hline DP3 & $\mathrm{C}_{20} \mathrm{H}_{19} \mathrm{FN}_{8} \mathrm{O}_{3}^{+}$ & 439.1598 & 439.1612 & -0.14 & 422,390 \\
\hline
\end{tabular}

\begin{tabular}{|c|c|c|c|c|}
\hline \multicolumn{5}{|c|}{ RIO } \\
\hline Position & ${ }^{1} \mathrm{H}$ & Chemical Shift(ס ppm) & Position & ${ }^{13} \mathrm{C}$ \\
\hline $1-3$ & $3 \mathrm{H}$ & $9.06(d), 8.60(d), 7.24(d)$ & 28 & 155.52 Ester \\
\hline $13-16$ & $4 \mathrm{H}$ & 7.12(d),7.31(m), $7.19(\mathrm{~d}), 7.31(\mathrm{~m})$ & $1-3$ & $148.89,117.89,133.82$ Aromatic $-\mathrm{CH}-$ \\
\hline 25 & $2 \mathrm{H}$ & $6.39, \mathrm{~s}$, absent in $\mathrm{D}_{2} \mathrm{O}$ exchange & 4,6 & 114.65, 155.09 Quaternary Carbon \\
\hline 26 & $2 \mathrm{H}$ & $6.41, \mathrm{~s}$, absent in $\mathrm{D}_{2} \mathrm{O}$ exchange & 7 & 141.78 Quaternary Carbon \\
\hline 10 & $2 \mathrm{H}$ & $5.81, \mathrm{~s}$ & 11,12 & 124.24, 161.04, Quaternary Carbon \\
\hline 27 & $3 \mathrm{H}$ & $3.03, \mathrm{~s}$ & $13,14,15,16$ & $115.52,129.74,124.53,129.83$ Aromatic $-\mathrm{CH}-$ \\
\hline 30 & $3 \mathrm{H}$ & $3.39, \mathrm{~s}$ & $18,20,21$ & $150.78,159.50,100.27,158.60$ Quaternary Carbon \\
\hline & & & 30 & $52.51, \mathrm{CH}_{3}$ \\
\hline & & & 10 & $43.87, \mathrm{CH}_{2}$ \\
\hline & & & 29 & $34.72, \mathrm{CH}_{3}$ \\
\hline
\end{tabular}

\begin{tabular}{|c|c|c|c|c|c|c|c|}
\hline \multicolumn{2}{|c|}{ RIO } & \multicolumn{2}{|c|}{ DP1 } & \multicolumn{2}{|c|}{ DP2 } & \multicolumn{2}{|c|}{ DP3 } \\
\hline $\begin{array}{l}\text { Wave number } \\
\qquad\left(\mathrm{cm}^{-1}\right)\end{array}$ & Assignments & $\begin{array}{l}\text { Wave } \\
\text { number } \\
\left(\mathrm{cm}^{-1}\right)\end{array}$ & Assignments & $\begin{array}{l}\text { Wave } \\
\text { number } \\
\left(\mathrm{cm}^{-1}\right)\end{array}$ & Assignments & $\begin{array}{c}\text { Wave } \\
\text { number } \\
\left(\mathrm{cm}^{-1}\right)\end{array}$ & Assignments \\
\hline 3508,3457 & $\mathrm{~N}-\mathrm{H}$ (Stretching) & 3463,3329 & $\begin{array}{c}\mathrm{N}-\mathrm{H} \\
\text { (Stretching) }\end{array}$ & 3515,3282 & $\begin{array}{c}\mathrm{N}-\mathrm{H} \\
\text { Stretching }\end{array}$ & $\begin{array}{l}3371 \\
3261 \\
3010\end{array}$ & $\begin{array}{c}\text { Broad peak } \\
\text { covering }-\mathrm{N}-\mathrm{H} \\
\text { Aromatic } \mathrm{C}-\mathrm{H} \\
\text { Stretching and }\end{array}$ \\
\hline \multirow[t]{3}{*}{$\begin{array}{c}3099 \\
3064,3035\end{array}$} & \multirow{3}{*}{$\begin{array}{l}\text { Aromatic } \mathrm{C}-\mathrm{H} \\
\text { and Methyl C-H } \\
\text { stretching }\end{array}$} & & & 3153 & $\begin{array}{c}\text { Aromatic C-H } \\
\text { Stretching }\end{array}$ & & N-oxide \\
\hline & & \multirow[t]{2}{*}{$\begin{array}{l}3266 \\
3125\end{array}$} & \multirow[t]{2}{*}{$\begin{array}{c}\text { Aromatic C-H } \\
\text { Stretching }\end{array}$} & \multirow[t]{2}{*}{2988,2967} & \multirow[t]{2}{*}{$\begin{array}{l}\text { Methyl C-H } \\
\text { Stretching }\end{array}$} & 2747 & $\begin{array}{l}\text { Methyl C-H } \\
\text { Stretching }\end{array}$ \\
\hline & & & & & & 1703 & $\begin{array}{l}\text { Ester } \mathrm{C}=\mathrm{O} \\
\text { Stretching }\end{array}$ \\
\hline 1688 & $\mathrm{C}=\mathrm{O}$ Stretching & \multirow[t]{4}{*}{$\begin{array}{c}1598 \\
1568,1459\end{array}$} & \multirow[t]{4}{*}{$\begin{array}{c}\text { Aromatic } \mathrm{C}=\mathrm{C} \\
\text { Bending }\end{array}$} & 1711 & $\begin{array}{l}\text { Carbonyl } \\
\text { C }=0 \\
\text { Stretching }\end{array}$ & 1636 & \multirow[t]{3}{*}{$\begin{array}{l}\text { Aromatic } \mathrm{C}-\mathrm{H} \\
\text { bending }\end{array}$} \\
\hline 1622 & \multirow{3}{*}{$\begin{array}{c}\text { Aromatic } \mathrm{C}=\mathrm{C} \\
\text { Stretching }\end{array}$} & & & 1639 & \multirow{3}{*}{$\begin{array}{l}\text { Aromatic } \mathrm{C}=\mathrm{C} \\
\text { stretching }\end{array}$} & 1633 & \\
\hline 1602 & & & & 1602 & & 1522 & \\
\hline 1505 & & & & 1596 & & & \\
\hline
\end{tabular}

absence of one of the methyl group at $52.52 \mathrm{ppm}$ (Table S2).

IR spectra: An IR spectrum of DP1 indicatesformation of secondary amino group at $3329 \mathrm{~cm}^{-1}$. It also indicates absence of carbamate group at $1688 \mathrm{~cm}^{-1}$ which is present in RIO.
DP1 is characterized as 2-(1-(2-fluorobenzyl)-1H-pyrazolo [3, 4-b] pyridin-3-yl)-N5-methylpyrimidine-4, 5, 6-triamine (Table 7).

\section{Structural elucidation of DP2}

MS/MS spectra: DP2 eluted at retention time of 9.4 min. ESI/MS/MS spectrumof DP2 showed protonated 


\begin{tabular}{|c|c|c|c|c|}
\hline \multicolumn{5}{|c|}{ DP1 } \\
\hline Position & ${ }^{1} \mathrm{H}$ & Chemical Shift (ס ppm) & Position & ${ }^{13} \mathrm{C}$ \\
\hline $25,26,27$ & $3 \mathrm{H}$ & $7.35(d), 8.6(d), 9.06(d)$ & $22,23,24$ & $\begin{array}{c}142.08,153.09,114.49 \\
\text { Quaternary carbon }\end{array}$ \\
\hline $15,16,17,18$ & $4 \mathrm{H}$ & $7.35(d), 7.13(d), 7.31(t), 7.12(d)$ & $25,26,27$ & $133.82,115.52,148.8$ Aromatic-CH- \\
\hline 2 & $2 \mathrm{H}$ & $6.09, \mathrm{~s}$, absent in $\mathrm{D}_{2} \mathrm{O}$ exchange & $15,16,17,18$ & $\begin{array}{l}\text { 129.92, } 124.52,129.81,115.31 \\
\text { Aromatic-CH- }\end{array}$ \\
\hline 3 & $2 \mathrm{H}$ & $6.09, \mathrm{~s}$, absent in $\mathrm{D}_{2}$ Oexchange & 19,20 & 161.05,124.56 Quaternary carbon \\
\hline 21 & $2 \mathrm{H}$ & $5.79, \mathrm{~s}$ & $11,12,13,14$ & $\begin{array}{c}158.61,106.98,158.26,150.78 \\
\text { Quaternary carbon }\end{array}$ \\
\hline 4 & $1 \mathrm{H}$ & $\begin{array}{c}\text { 3.39,s-NH,absent in } \\
\mathrm{D}_{2} \mathrm{O} \text { exchange }\end{array}$ & 21 & $43.75, \mathrm{CH}_{2}$ \\
\hline 1 & $3 \mathrm{H}$ & $2.51, d$ & 1 & $33.06, \mathrm{CH}_{3}$ \\
\hline
\end{tabular}
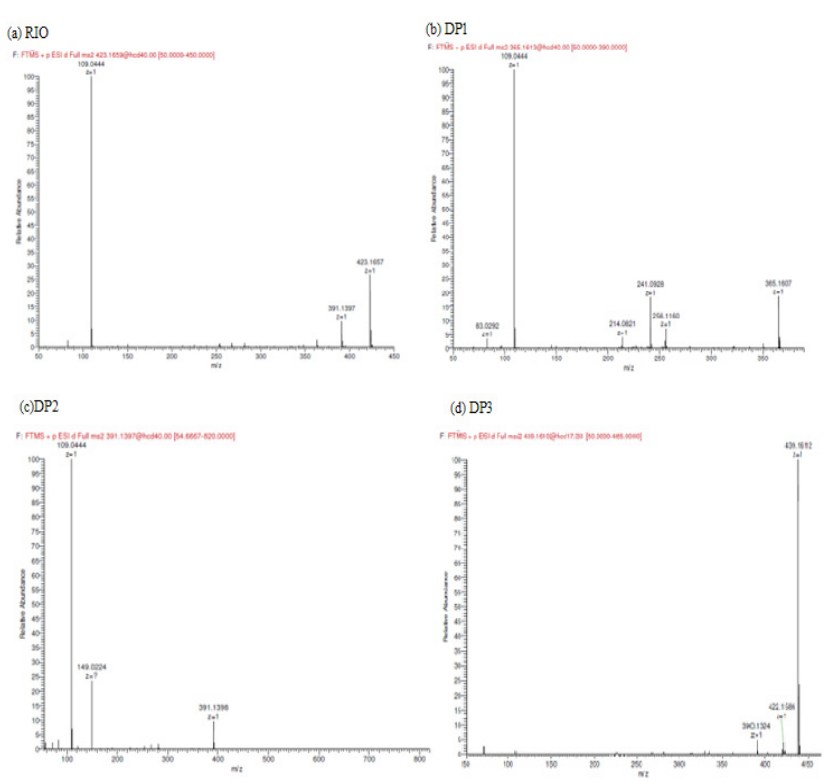

Figure 6: ESI-MS/MS spectra of RIO, DP1, DP2 and DP3.
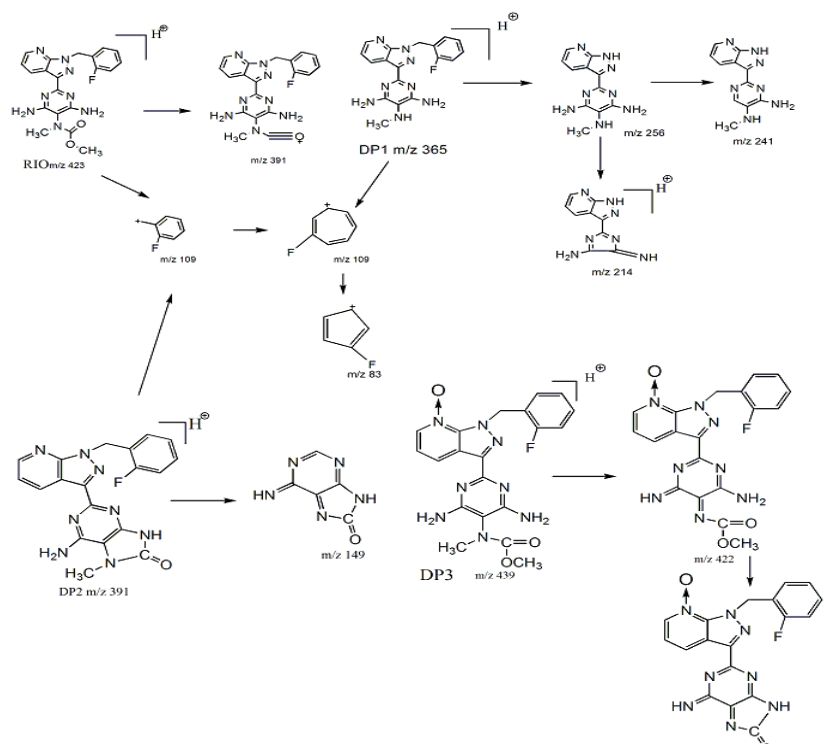

Figure 7: Mass spectral fragmentation of RIO and its degradation products.

DP2 is characterized as 2-(1-(2-fluorobenzyl)-1H-pyrazolo [3, 4-b] pyridin-3-yl)-6-amino-7-methyl-7H-purin-8(9H)one.

\section{Structural elucidation of DP3}

MS/MS spectra: DP3 is formed in oxidative condition. DP3 elutes at retention time of $4.1 \mathrm{~min}$.ESI/MS/MS spectrum of DP3 shows protonated molecular ion at 439.1612corresponding with elemental composition of $\mathrm{C}_{20} \mathrm{H}_{19} \mathrm{FN}_{8} \mathrm{O}_{3}{ }^{+}$(Table 6) shows fragment ions of $\mathrm{m} / \mathrm{z}$ 422 (loss of methane from $\mathrm{m} / \mathrm{z} 439$ ), $\mathrm{m} / \mathrm{z} 390$ (loss of methanol from $m / z$ 422) (Figure 6d and 7).

NMR spectra: The number of protons and number of carbons in DP3 are same in ${ }^{1} \mathrm{H}$ and ${ }^{13} \mathrm{C}$ NMR spectra as that of RIO. In the protons of pyridine ring chemical shift is observed in three protons compared to RIO which indicates that formation of $\mathrm{N}$-oxide has taken 


\begin{tabular}{|c|c|c|c|c|}
\hline \multicolumn{5}{|c|}{ Table S3: NMR assignments of DP2. } \\
\hline \multicolumn{5}{|c|}{ DP2 } \\
\hline Position & ${ }^{1} \mathrm{H}$ & Chemical Shift $(\delta \mathrm{ppm})$ & Position & ${ }^{13} \mathrm{C}$ \\
\hline 12 & $1 \mathrm{H}$ & $11.6,-\mathrm{NH}$ absent in $\mathrm{D}_{2} \mathrm{O}$ exchange & 1 & 152.52, imidazolinone \\
\hline $13,16,19$ & $3 \mathrm{H}$ & $9.06(\mathrm{~d}), 8.63(\mathrm{~d}), 7.37(\mathrm{~d})$ & $13,16,19$ & $149.06,117.98,133.37$ Aromatic-CH- \\
\hline $18,21,24,25$ & $4 \mathrm{H}$ & $7.22(\mathrm{~d}), 7.35(\mathrm{~d}), 7.24(\mathrm{~d}), 7.20(\mathrm{~d})$ & $22,29,17$ & $114.27,152.92,141.39$, Quaternary carbon \\
\hline 5 & $2 \mathrm{H}$ & $6.76, \mathrm{~s},-\mathrm{NH}_{2}$ absent in $\mathrm{D}_{2} \mathrm{O}$ exchange & $18,21,24$ & $124.56,130.16,129.91$, Aromatic $-\mathrm{CH}-$ \\
\hline 28 & $2 \mathrm{H}$ & $5.80, \mathrm{~s}$ & $25,26,27$ & $115.55,161.33,124.59$, Quaternary carbon \\
\hline 11 & $3 \mathrm{H}$ & $3.49, \mathrm{~d}$ & $14,15,20,23$ & $150.78,158.68,147.8,105.19$, Quaternary \\
& & & & carbon \\
\hline & & & 28 & $43.87 \mathrm{CH}_{3}$ \\
\hline
\end{tabular}

\begin{tabular}{|c|c|c|c|c|}
\hline \multicolumn{5}{|c|}{ DP3 } \\
\hline Position & ${ }^{1} \mathrm{H}$ & Chemical Shift ( $\delta$ ppm) & Position & ${ }^{13} \mathrm{C}$ \\
\hline $1,2,3$ & $3 \mathrm{H}$ & 8.65(d), 7.41(s), $8.54(d)$ & $1,2,3$ & $149.06,117.47,134.34$ Aromatic $-\mathrm{CH}-$ \\
\hline $26,27,28,29$ & $4 \mathrm{H}$ & $7.18(d), 7.27(d), 7.23(d), 7.31(d)$ & $4,5,7$ & 114.86, 152.86, 137.25 Quaternary carbon \\
\hline 17 & $2 \mathrm{H}$ & $\begin{array}{l}7.2, \mathrm{~s},-\mathrm{NH}_{2} \text { absent in } \mathrm{D}_{2} \mathrm{O} \\
\text { exchange }\end{array}$ & $10,12,13,14$ & $140.09,158.66,99.96,158.76$ Quaternary carbon \\
\hline 16 & $2 \mathrm{H}$ & $\begin{array}{l}\text { 6.8, } \mathrm{s},-\mathrm{NH}_{2} \text { absent in } \mathrm{D}_{2} \mathrm{O} \\
\text { exchange }\end{array}$ & $24,25,26,27,28,29$ & $\begin{array}{c}124.62,161.10,115.59,129.96,123.87,130.21 \\
\text { Aromatic }-\mathrm{CH}-\end{array}$ \\
\hline 23 & $2 \mathrm{H}$ & $5.81, \mathrm{~s}$ & 20 & 154.99 Ester \\
\hline 19 & $3 \mathrm{H}$ & $3.49,3.46, d$ & 22 & $52.61 \mathrm{CH}_{3}$ \\
\hline \multirow[t]{2}{*}{22} & $3 \mathrm{H}$ & $2.90, \mathrm{~s}$ & 23 & $43.94 \mathrm{CH}_{2}$ \\
\hline & & & 19 & $34.54 \mathrm{CH}_{3}$ \\
\hline
\end{tabular}

place in pyridine ring and there is chemical shift value in these protons (Table S4).

IR spectra: IR spectra of DP3 indicates broad peak in region at $3371 \mathrm{~cm}^{-1}$ which indicatesformation of N-oxide (Table 7).

DP3 is characterized as methyl 2-(1-(2-fluorobenzyl)1H-pyrazolo [3, 4-b] pyridin-3-yl)-4, 6-diaminopyrimidin-5-ylmethylcarbamate-N-oxide.

\section{Degradation behavior of RIO}

The chemical structure of RIO contains pyridine ring fused with pyrazole ring, flurobenzene ring, pyrimidine ring and $\mathrm{N}$-methyl carbamate. Carbamate group is susceptible to hydrolysis. DP1 and DP2 are formed under alkaline condition. DP1 is formed from RIO by bimolecular addition elimination reaction in which there is addition of hydroxide ion to carbamate group and formation of tetrahedral intermediate. ${ }^{21}$ Tetrahedral intermediate loses methoxy group and corresponding acid is formed. Acid undergoes elimination of carboxylate and DP1 is formed. DP2 is formed by loss of methoxy group and as a result there is intra molecular cyclisation between carbonyl group and amino group of pyrimidine
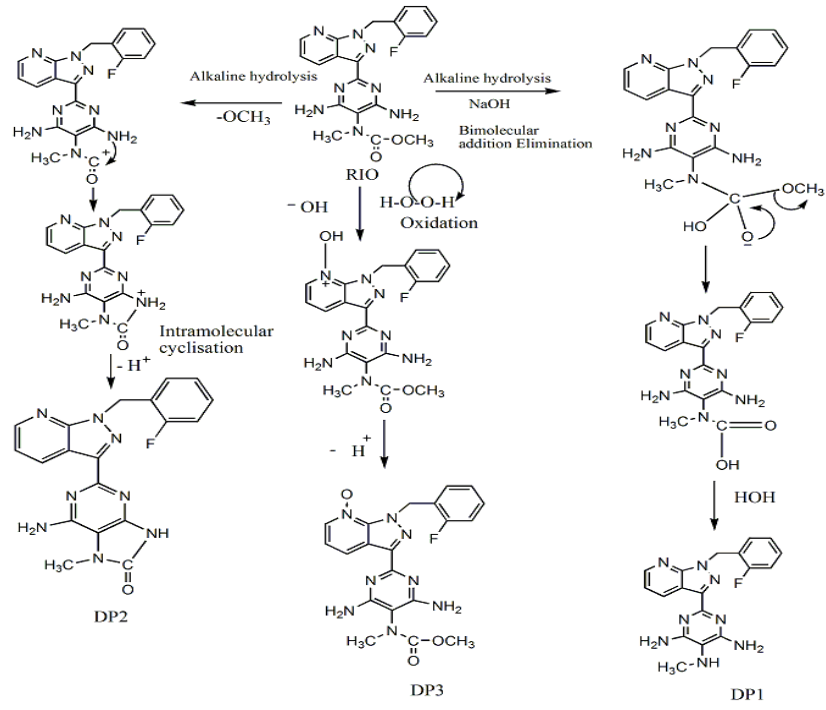

Figure 8: Degradation pathway of RIO.

ring and formation of DP2. Under oxidative condition, from hydrogen peroxide reagent, there is attack of hydroxide ion on pyrimidine ring, with further loss of proton, there is formation of N-oxide (DP3) (Figure 8). 


\section{CONCLUSION}

Stability indicating method was developed for determination of Riociguat. Forced degradation studies were performed to evaluate stability indicating method. Degradation was observed in alkaline and oxidative conditions while Riociguat was found to be stable in acidic, neutral hydrolytic, thermal and photolytic conditions. Degradation products were well separated from Riociguat. The developed method was validated as per ICH guidelines. The robustness of the developed method was adjusted by application of QbD using fractional factorial design. Two degradation products in alkaline conditions and one in oxidative condition were isolated by preparative HPLC and characterized by LC-HR-MS/MS, NMR and IR techniques. DP1 is formed from RIO by bimolecular addition elimination reaction while DP2 is formed from intramolecular cyclisation of RIO. DP3 is formed from RIO by oxidation by formation of $\mathrm{N}$-oxide. The structure and degradation pathways for degradation products were proposed on the basis of LC-HR-MS/MS. The method is simple, accurate and fast. It is applicable to assay the drug substance, for long term stability studies and also to kinetic studies.

\section{ACKNOWLEDGEMENT}

The authors are thankful to UGC for providing UGCBSR (RFSMS) fellowship to carry out the present work.

\section{CONFLICT OF INTEREST}

Authors declare that there are no conflicts of interest.

\section{ABBREVIATIONS}

ML: Milliliter; DP: Degradation Product; HPLC: High Performance Liquid Chromatography; LC-HRMS: Liquid Chromatography Mass Spectrometry; NMR: Nuclear Magnetic Resonance; IR: Infrared; APT: Attached Proton Test; ICH: International Conference on Harmonization; $\mu \mathrm{L}$ : Microlitre; DoE: Design of Experiments; QbD: Quality by Design; ANOVA: Analysis of Variance; PDA: Photo Diode Array; ppm: Parts per million.

\section{REFERENCES}

1. https://pubchem.ncbi.nlm.nih.gov./compound/11304743 (accessed on Apr.11, 2019).

2. https://www.drugbank.ca/drugs/DB08931 (accessed on Apr. 11, 2019).
3. Ghofrani HA, D'Armini AM, Grimminger F, Hoeper MM, Jansa P, Kim NH, et al. Riociguat for the treatment of chronic thromboembolic pulmonary hypertension. N Engl J Med. 2013;369(4):319-29.

4. Rubin LJ, Galie N, Grimminger F, Grunig E, Humbert M, Jing ZC, et al. Riociguat for the treatment of pulmonary arterial hypertension: A long-term extension study (Patent-2). The Euro Respir J. 2015;45(5):1211-3.

5. https://www.accessdata.fda.gov/drugsatfda_docs/label/2017/204819s006lbl.

6. Hill NS, Rahagahi FF, Sood N, Frey N, Ghofrani HA. Individual dose adjustment of riociguat in patients with pulmonary arterial hypertension and chronic thromboembolic pulmonary hypertension. Resp Med. 2017;129:124-9.

7. Chakravarthy AV, Sailaja BV, Praveen K. Method development and validation of ultraviolet-visible spectroscopic method for the estimation of assay of sugammadex sodium, apremilast, riociguat and vorapaxar sulphate drugs in active pharmaceutical ingredient form. Asian J Pharm Clin Res. 2017;10(2):241-50.

8. Temigire PR, Sobia G, Muniipalli VK, Warde S, Singh RM, Nayak S, et al. Development and validation of reverse-phase high performance liquid chromatography method for quantitative estimation of riociguat in tablet dosage form. J Pharmacy Res. 2017;12(4):461-5.

9. Meyynathan SN, Nayak R, Narenderan ST, Sai KLV, Kalaivani M, Basvan B. Analytical method development and validation for the determination of Riociguat in their formulations by LC-MS/MS. J Global Pharma Tech. 2018;10(12):19-23.

10. Gnoth NJ, Hopfe PM, Czembor W. Determination of riociguat and its major human metabolite $\mathrm{M}-1$ in human plasma by stable-isotope dilution LCMS/ MS. Bioanalysis. 2015;7(2):193-205.

11. Tiwari SS, Chavan BB, Kushwah BS, Yerra NV, Mukesh S, Sangam AT, et al. In vitro and in vivo investigation of metabolic fate of riociguat by HPLC-QTOF/MS/MS and in silico evaluation of the metabolites by ADMET predictor ${ }^{\mathrm{TM}}$. $\mathrm{J}$ of Pharm Biomed Anal. 2019;164: 326-36.

12. ICH. Q3A(R2). International Conference on Harmonisation, IFMPA, Geneva, Switzerland. 2003.

13. $\mathrm{ICH}$. Impurities in new drug products $\mathrm{Q} 3 \mathrm{~B}(\mathrm{R} 2)$. International Conference on Harmonisation, IFMPA, Geneva, Switzerland, 2003.

14. Bhutani H, Kurmi M, Singh S, Beg S, Singh B. Quality by design in analytical sciences an overview. Pharma Times. 2014;46(8):71-5.

15. Schimdt $\mathrm{AH}$, Stanic M, Molnar I. In silico robustness testing of a compendia HPLC purity method by using a multidimensional design space build by chromatography modeling-case study pramipexole. J Pharm Biomed Anal. 2014;91:97-107.

16. Ferreira SLC, Caires AO, Borges TS, Lima AM, Silva LO, Santos WN. Robustness evaluation in analytical methods optimized using experimental designs. Microchem J. 2017;131:163-9.

17. International Conference on Harmonization, Q1A(R2) Stability Testing of New Drug substances and products, Consensus Guidelines, $\mathrm{ICH}$ Harmonized Tripartite Guidelines. 2003

18. International Conference on Harmonization, Q2(R1) Validation of Analytical Procedures: Methodology, Consensus Guidelines, ICH Harmonized Tripartite Guidelines. 1996.

19. Food and Drug Administration. Guidance for Industry: Analytical Procedures and Methods Validation for Drugs and Biologics. 2000.

20. International Conference on Harmonization, Q1B Stability testing: Photostability testing of new drug substances and products, Consensus Guidelines, ICH Harmonized Tripartite Guidelines. 1996.

21. Silva D, Norberto F, Santos S, Herves P. Alkaline hydrolysis of tertiary $\mathrm{N}$-(2-pyridyl) carbamates, contradictory evidence between nucleophilic and general base catalysis. Reaction Kinetics, Mechanism and Catalysis. $2015 ; 115(2): 421-30$. 


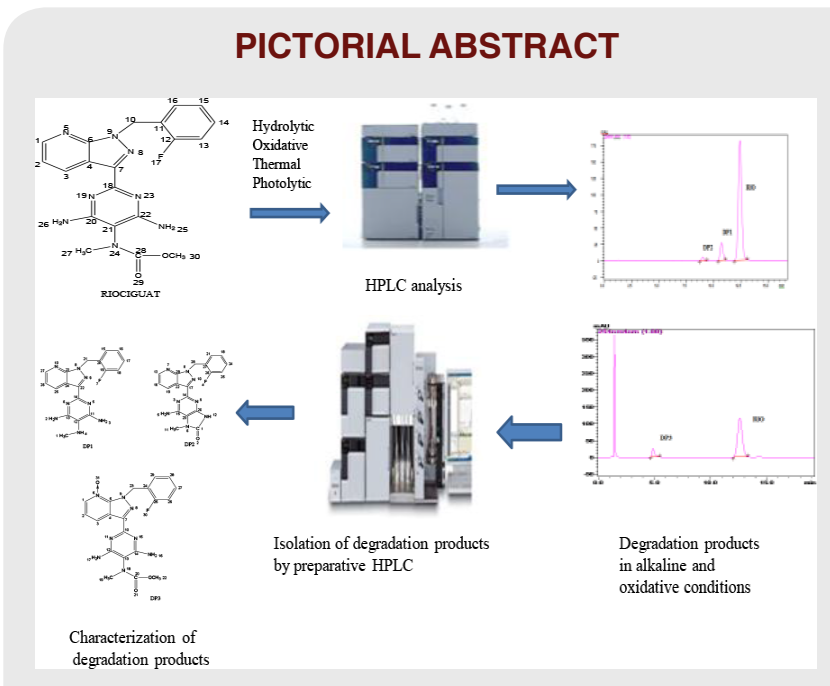

\section{SUMMARY}

Stability indicating method was developed for determination of Riociguat and was developed as per ICH guidelines. Riociguat was subjected to ICH prescribed stress degradation conditions. Degradation was observed under alkaline and oxidative conditions. Degradation products were identified, isolated and characterized by LC-HR-MS/MS, NMR and IR techniques.

\section{About Authors}

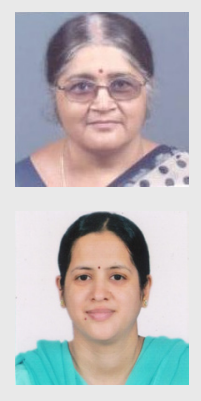

Sadhana Rajput, Rajput is a Professor and Dean in Pharmaceutical Quality Assurance Department at Faculty of Pharmacy, The Maharaja Sayajirao University of Baroda. Her area of interest are Development of Analytical Methods, Impurity profiling, Development of modified release formulations and standardization of herbal formulations

Charu P Pandya, is a Ph.D. research scholar working at The Maharaja Sayajirao University of Baroda enrolled in Pharmaceutical Quality Assurance Department under the Faculty of Pharmacy. She has completed her M.Pharm form J.S.S. College of Pharmacy, Ooty and M.B.A. from I.P.E.R. Pune Pvt. Ltd. She is currently working on projects involving quality by design and impurity profiling.

Cite this article: Pandya CP, Rajput SJ. Stress Degradation Studies of Riociguat, Development of Validated Stability Indicating Method, Identification, Isolation and Characterization of Degradation Products by LC-HR-MS/MS and NMR Studies. Indian J of Pharmaceutical Education and Research. 2019;53(4s):s630-s641. 